\title{
Environmental Determinants Influencing Seasonal Variations of Bird Diversity and Abundance in Wetlands, Northern Region (Ghana)
}

\author{
Collins Ayine Nsor ${ }^{1}$ and Edward Adzesiwor Obodai ${ }^{2}$ \\ ${ }^{1}$ Center for Savannah Ecosystem Research (CESER), P.O. Box TL 861, Tamale, Ghana \\ ${ }^{2}$ Department of Fisheries and Aquatic Sciences, University of Cape Coast, University Post Office, Cape Coast, Ghana \\ Correspondence should be addressed to Collins Ayine Nsor; ayineus@yahoo.com
}

Received 28 May 2014; Revised 10 August 2014; Accepted 14 September 2014; Published 29 October 2014

Academic Editor: Greg Demas

Copyright (C) 2014 C. A. Nsor and E. A. Obodai. This is an open access article distributed under the Creative Commons Attribution License, which permits unrestricted use, distribution, and reproduction in any medium, provided the original work is properly cited.

\begin{abstract}
The study assessed major environmental determinants influencing bird community in six wetlands over a 2-year period. A combination of visual and bird sounding techniques was used to determine the seasonal variations in bird abundance, while ordination techniques were performed to determine the influence of environmental factors on bird assemblage. A total of 1,169 birds from 25 species and 885 individuals from 23 species were identified in the wet and dry season, respectively. The shallow close marshes supported the greatest number of birds $(P<0.05)$ compared to the riparian wetlands. Bird diversity was significantly higher in the wet season than in the dry season $(F=4.101, P<0.05)$. Cattle egret (Bubulcus ibis) and marsh warbler (Acrocephalus palustris) were the most abundant. Using the IUCN "Red List" database guide, we noted that $96.2 \%$ of birds identified were least concern (LC). The yellow weaver bird (Ploceous megarhrynchus) was the only vulnerable species (VU) and represented $3.8 \%$. From the three variables tested, bushfire and farming practices were the major threats and cumulatively explained 15.93\% (wet season) and $14.06 \%$ (dry season) variations in bird diversity and abundance. These findings will help wetland managers design conservation measures to check current threats on birds from becoming vulnerable in the future.
\end{abstract}

\section{Introduction}

Birds play a vital role in enriching the biodiversity of wetlands. This explains why wetlands are foremost recognized as a haven for waterfowl by Ramsar International in 1971 [1]. Their sensitivity to habitat perturbation makes them suitable as bioindicators to wetland health, through their population size and composition. Globally, over 150 bird species are reportedly lost since the year $1500 \mathrm{AD}$ [2]. Recent reports have shown that birds have gone extinct at an exceptionally high rate, estimated to be 1,000 to 10,000 times the natural background rate [2]. Today, one in eight bird species is threatened with global extinction, with 190 species critically endangered and particularly alarming are sharp declines in a number of formerly common and widespread species, such as cranes and some waders. The International Union for the Conservation of Nature (IUCN) "Red List" have shown documented evidence that rate of extinction is getting worse among species confined to small islands to continental scale [2]. This loss is largely due to their increasingly intolerance to the slightest ecosystem disturbance [3] which is linked to pollution [4], habitat type and bird distribution $[5,6]$, wetland patch size [7], cutting of mangrove vegetation [8], farming practice and urban development within the wetland catchment [9-11], and habitat fragmentation [12]. These human disturbances at the landscape scale have structured the population and assemblages of birds because of their highly specific habitat requirements $[13,14]$.

Scientific studies on bird ecology, diversity, abundance, and spatial distribution are simply absent or poorly investigated in the Northern Savannah wetlands of Ghana. However, unlike the Northern Region, research on birds in the Southern forest belt [15-17] and coastal wetlands has been considerably extensive [18-22]. The only notable work 
previously conducted in one of the wetlands under the current study (Kukobila wetland) was to establish a baseline of the types of birds found in the wetland [23]. Understanding overall bird responses to disturbances will as well require the assessment of the various disturbance scenarios on a seasonal basis, since the impacts of environmental determinants are many and vary along seasonal trends. Ecological changes and land use activities within wetlands catchment in Northern Region of Ghana are seasonally driven and can potentially affect bird assemblage, composition, and habitat preference. Of the 728 bird species recorded in Ghana [18-20] six of them are considered threatened and 12 near threatened [24]. For example the National Biodiversity Strategy for Ghana Report mentioned hornbill, parrots, and birds of prey, as the few keystone species under threat [25]. Though these findings were largely from the southern sector of Ghana (i.e., forest belt and coastal zones), the phenomenon suggests that some birds in the Northern Savannah zone might be under threat or at risk of extinction, giving recent undocumented, but observed, environmental disturbances on the wetlands. Therefore, the absence of a scientific investigation makes it impossible to determine the current state of bird population, composition, and habitat preference (using their proximate cues), on a seasonal basis among wetlands in the Northern Savannah zone. In this study, we apply multivariate ordination techniques to determine the influence of three environmental factors on the seasonal variation of bird population, diversity, and habitat preference among the wetlands. The outcome of this investigation will help equip wetland managers with first-hand information on the types of seasonal disturbance scenarios and how these disturbances could potentially modify bird assemblage in the future and the selection of appropriate conservation approach towards enhancing the sustainability of their population.

\section{Methods}

The study was carried out in six wetlands located in the Northern Region of Ghana, with their coordinates as follows: (i) Wuntori (N09 $\left.08.335^{\prime} \mathrm{W}^{\circ} 0^{\circ} 109^{\circ} .685^{\prime}\right)$; (ii) Kukobila $\left(\mathrm{N} 10^{\circ} 08.723^{\prime} \mathrm{W}_{000}^{\circ} 48.179^{\prime}\right)$; (iii) Tugu (N09 $22.550^{\prime} \mathrm{W} 000^{\circ}$ 35.004'); (iv) Bunglung (N09 $\left.35.576^{\prime} \mathrm{W}^{\circ} 000^{\circ} 47.443^{\prime}\right)$; (v) Adayili (N09 $41.391^{\prime} \mathrm{W}^{\circ} 000^{\circ} 41.480^{\prime}$ ); and (vi) Nabogo (N09 ${ }^{\circ}$ $49.941^{\prime}$ W000 $0^{\circ} .51 .942^{\prime}$ ) (Figure 1). The six sites lie on the extensive floodplain along the course of the White Volta River, which has over time become incised and modified through meandering and aligning along various topographic features. This has led to the development of streams that have diverted from the main White Volta [26]. All six wetlands were classified as close shallow marshes (Wuntori and Tugu wetlands), open deep marsh (Kukobila wetland), riparian wetlands (Adayili and Nabogo wetlands), and artificial wetland (Bunglung wetland). The hydrological regimes of the six wetlands under study were typical of permanent wetlands, whose depth at low tide did not exceed $2 \mathrm{~m}$ on average. Sizes of the wetlands were as follows: (a) Wuntori $=7.7$ ha; (b) Kukobila $=5$ ha, Tugu (c) 2.7 ha; (d) Nabogo $=7.9$ ha; (e) Adayili $=6.7$ ha; and (f) Bunglung $=11.5$ ha.
Annual rainfall is in the range of $1000-1,300 \mathrm{~mm} / \mathrm{p} . \mathrm{a}$ and the wet season lasts from June to early October, while the dry season last from November to May. Average temperature varies between $14^{\circ} \mathrm{C}$ and $40^{\circ} \mathrm{C}$ [27]. Altitude ranges between 108 and 138 meters above mean sea level. The vegetation cover is a mixture of grassland dominated by Leersia hexandra and woodland dominated by Mahogany (Khaya senegalensis) and shea tree (Vitellaria paradoxa) interspersed with shrubby communities of Mitragyna inermis and Ziziphus abyssinica. The trees are relatively short with thick bark and occlusions, signifying their adaptation to the cyclical dry season bush fires. Crop farming, livestock rearing, and fishing are the main stay of activities among the inhabitants.

2.1. Sampling Procedure for Bird Species. Population monitoring survey was used to determine the seasonal variations in bird population, using transects line approach [28]. Ten plots in each of the six wetlands of $60 \mathrm{~m} \times 10 \mathrm{~m}$ dimension were laid. The distance between one sampling plot and the other was $5 \mathrm{~m}$. Birds were counted each of the ten plots with increasing five class distance scale (1-10, 10-20, 20$40,40-50$, and $50-60 \mathrm{~m}$ ) from the base of the transect line, using visual approach, and vocally through bird sounding technique developed by $[27,29]$. Bird sounding technique is software of recorded sounds of different birds, accompanying their names and photos. This vocal technique was only used to count birds that were hidden in dense vegetation and were difficult to visualize. This was made possible after observing and listening to the same bird screech, chirps, or tweet in the open vegetation in previous sampling. Repeated and careful listening of the bird sound in the thick vegetation for 5 minutes was followed by playing the composed sound in order to identify the right bird. Also, birds that were hidden in the thicket vegetation were counted through a deliberate agitation of the vegetation. This was done, by carefully throwing a stone inside the dense vegetation, in order to force the hidden bird(s) to fly out. They were counted after settling on the open vegetation. Counting of birds was done from 0700-01100 GMT when most of the birds were feeding. Counting was done once a week and hence four times in month. Birds were counted in the dry (harmattana period characterized by low humidity, high temperatures, foggy condition, and sandy storms) and wet seasons (rainy period). The total number of birds recorded was compiled on a monthly basis. Bird nest was not counted, since it was impossible to establish the type and number of birds cohabitating a nest. A pair of Bushnell Falcon binoculars with a $10 \times 50 \mathrm{~mm}$ dimension was used to observe birds located beyond $20 \mathrm{~m}$ distance for morphological features like colour and structure of the beak, colour of tail feather, colour of feathers around the neck, colour of the head feathers and the presence of comb-like feathers (see [30]).

2.2. Environmental Assessment. Identifying how many and which types of human-induced disturbances or threats are present and their regime is important when assessing the status of wetlands of high conservation concern for efficient management [31-34]. In this regard, four environmental 


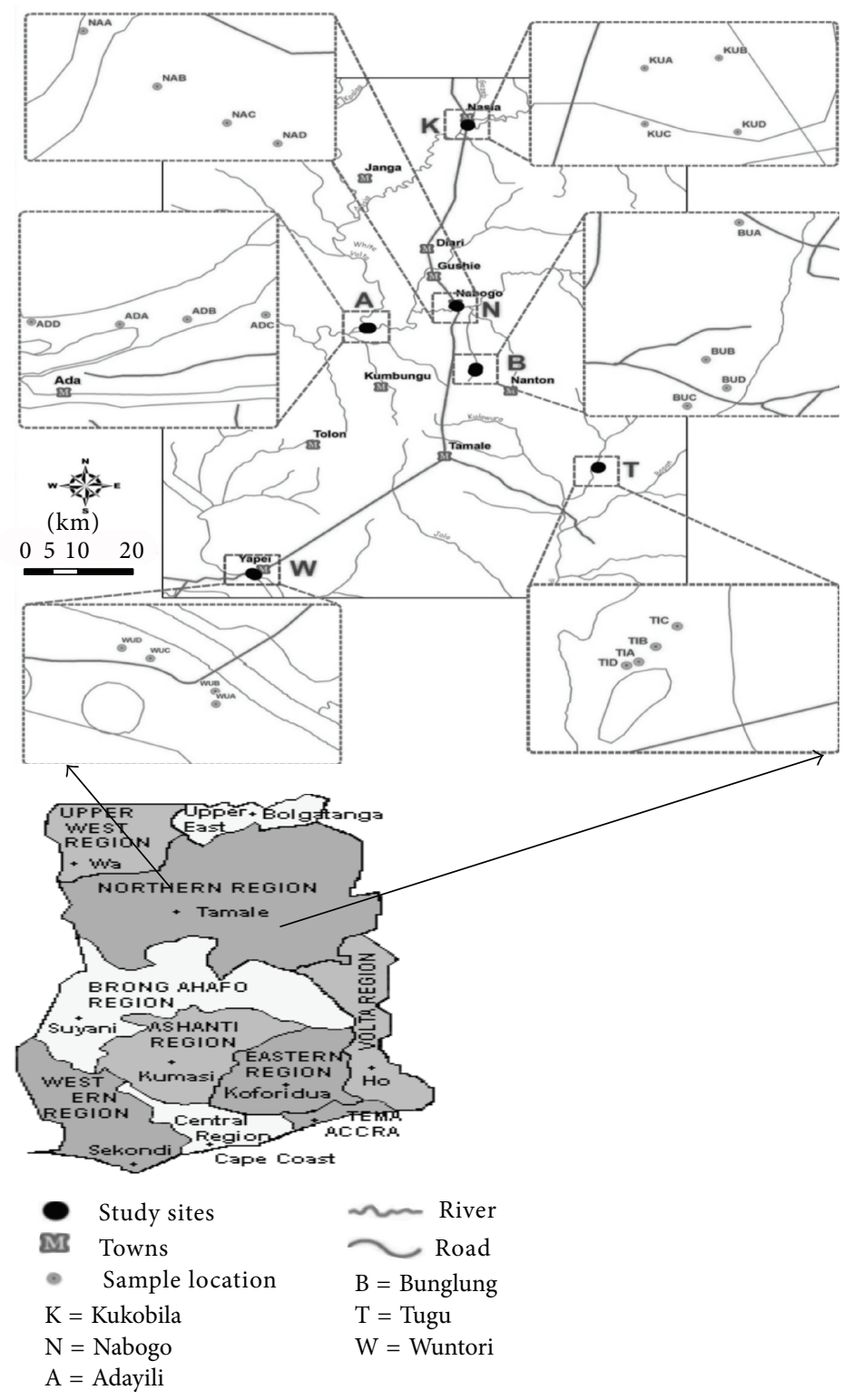

Figure 1: Map of the study areas, showing the location of the wetlands in the floodplains of the White Volta River catchment, Northern Region.

drivers of change, namely, bushfire, farming activities grazing, and erosion, were assessed to determine the severity of these threats on birds. The hierarchical classification of these threats was comprehensive (contains all possible items, at least at higher levels of the hierarchy), consistent (ensures that entries at a given level of the classification are of the same type), expandable (enables new items to be added to the classification if they are discovered), and exclusive (allows any given item to only be placed in one cell within the hierarchy) (see [35]). A score ranging from 1 to 4 (1 being the lesser impact and 4 the highest impact) was used to assess scope and severity of every threat. More precisely, for "scope" we referred to the percentage ratio of the study area affected by a specific threat within the last 5 years (where $100 \%$ correspond to total site area: $\chi$ ha) [36]. The scores were assigned as follows: 4: the threat is found throughout (50\%) the site area; 3: the threat is spread in $15-50 \%$ of the study area; 2 : the threat is scattered (5-15\%); and 1: the threat is much localized $(<5 \%)$. Assessment of the area disturbed was carried out within $1.2 \mathrm{~km}$ radius starting from the hydric delineated zone of the wetland. This is because all land use activities assessed were observed within the stated radius following a preliminary survey of the wetlands.

2.3. Statistical Analysis. A canonical correspondence analysis (CCA) was performed to determine the influence of environmental drivers of change on variations on bird diversity, abundance, and spatial distribution [37], using two analytical packages-environmental community analysis version 1.4 (ECOM.exe) [38]. Shannon-Weiner index was performed to 


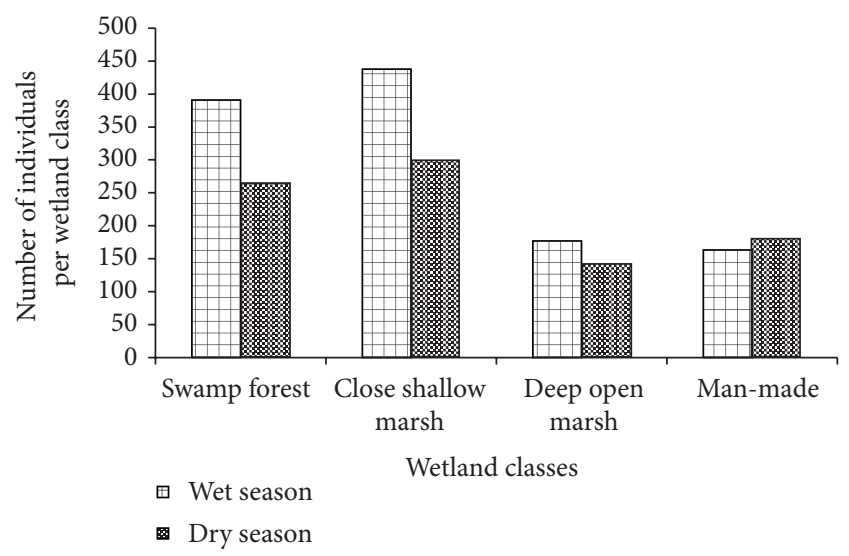

FIGURE 2: Comparison of bird population and distribution pattern among the different wetland classes in both wet and dry seasons.

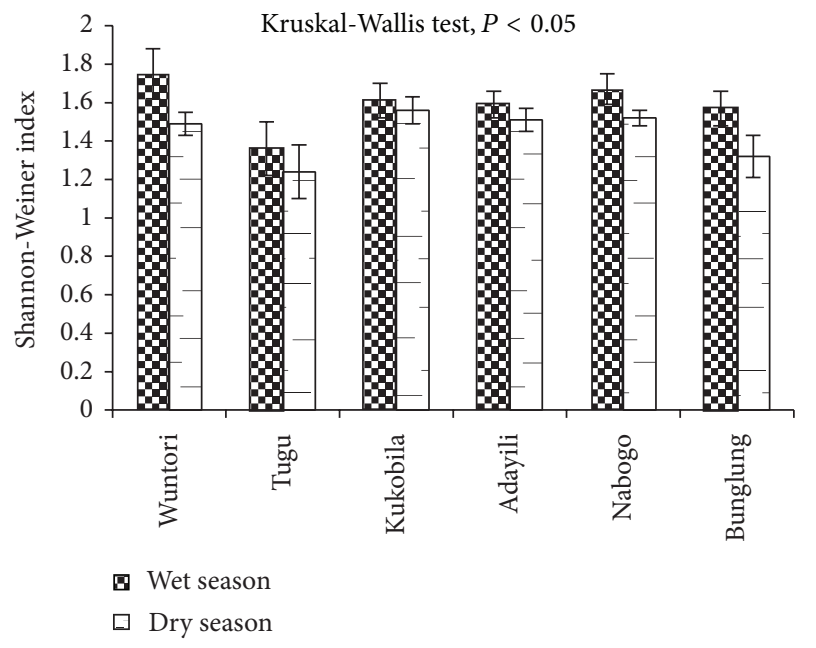

FIGURE 3: Variations in mean diversity in the wet and dry season.

determine the current status of bird community composition. Shannon-Weiner index equation was expressed as

$$
H^{\prime}=-\sum_{i=1}^{s} p i(\ln p i)
$$

where $s$ is the number of species and $p i$ is the proportion of individuals or the abundance of the $i$ th species expressed as a proportion of the total cover and $\ln$ is a natural logarithm [39]. Species evenness distribution (see Figure 4) was evaluated using Pielou evenness index $(J)$ expressed as

$$
J=\frac{H^{\prime}}{\ln S}
$$

where $H^{\prime}$ is the diversity index, $S$ is species number, and $\ln$ is natural logarithm [40]. Species richness was quantified using Margalef's index $(D)$ for species richness expressed as

$D=(S-1) / \ln N$ [41]. A one-way ANOVA was applied to test whether bird diversity, evenness, and species richness differed significantly from one wetland to the other, using

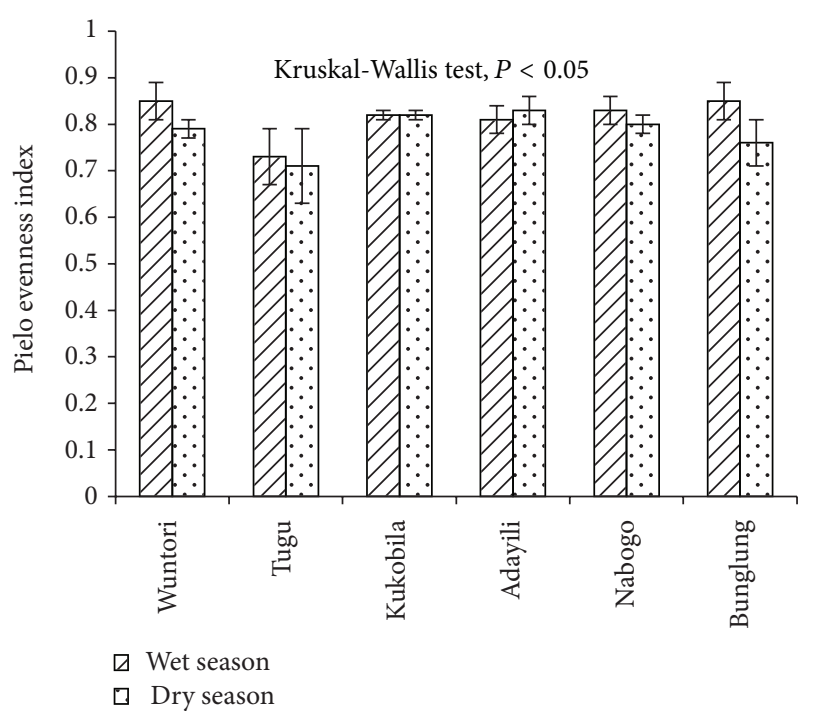

FIGURE 4: Bird evenness distribution of birds in the wet and dry seasons.

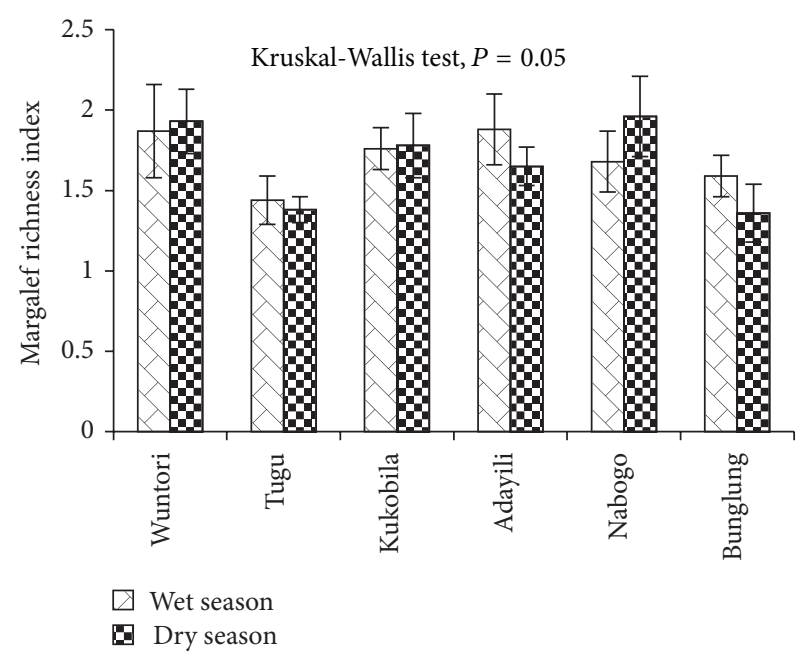

FIgURE 5: Comparison of bird richness in the six wetlands in wet and dry seasons.

SPSS version 16.0. Kruskal-Wallis test was applied to test the differences in the mean of the diversity index (Figure 5).

\section{Results}

A total of 1169 individual birds from 25 species were identified and counted during the wet season, while 885 individuals from 23 species were observed in the dry season (Figure 2, Table 1). Of the 25 species counted, 24 species $(96.2 \%)$ were classified as least concern (LC), using the IUCN "Red List" database guide (Table 1). The yellow weaver bird (Ploceus megarhrynchus) was the only species classified as vulnerable (VU) and represented 3.8\%. This species was restricted to thorny tree (Ziziphus abyssinica) and some tufted and rough edge grasses such as Diplachne fusca along the banks of Nabogo forested and the Bunglung man-made wetlands. All 
bird species were classified into 21 bird groups, of which waders, finches and pigeon, and doves had two species each classified under them (Table 1). Cattle egret (Bubulcus ibis) was the single most abundant species in the wet season while marsh warbler (Acrocephalus palustris) was the single most abundant species in the dry season (Table 1). Overall, the shallow close marshes of Wuntori and Tugu were the most preferred habitats for birds, followed by the riparian wetlands (Adayili and Nabogo) (Figure 2). Birds population in the three marshes (Tugu, Wuntori, and Kukobila wetlands) and the two riparian wetlands substantially differed in both seasons $(P<0.05)$, whereas species in artificial wetland (Bunglung) did not vary significantly $(P>0.05)$.

Mean number of birds in each line transect per plot ranged from $2.0 \pm 0.5$ to $11.6 \pm 2.8$ in the wet season and $2.2 \pm 0.5$ to $9.6 \pm 4.4$ in the dry season (Tables 2 (a) and 2(b)). Nabogo wetland registered the highest mean number of birds per plot while Bunglung artificial wetland was the least recorded in the wet season. Overall, mean bird diversity in the wet season $\left(H^{\prime}=1.361 \pm 0.14\right.$ and $\left.1.75 \pm 0.13\right)$ was significantly higher than that of the dry season $\left(H^{\prime}=\right.$ $1.24 \pm 0.14$ and $1.56 \pm 0.07)(F=4.101 ; P<0.05)$ (Figure 3$)$. Bird diversity generally followed their evenness distribution among the wetlands $(U=0 ; P<0.01$, Mann-Whitney $U$ test) but did not vary significantly from richness $(U=$ 9.5; $P>0.05$, Mann-Whitney $U$ test). Comparatively, the marshes (Wuntori and Kukobila) were more diverse in the wet $\left(H^{\prime}=1.75 \pm 0.13\right)$ and dry $\left(H^{\prime}=1.56 \pm 0.07\right)$ seasons, respectively, than in the riparian wetlands (Nabogo- $H^{\prime}=$ $1.67 \pm 0.08$ wet; $H^{\prime}=1.52 \pm 0.04$ dry) (Figure 3 ). On species richness, however, the riparian wetlands (e.g., Nabogo) were more species rich $(D=1.96 \pm 0.25)$ than the marshes (e.g., Wuntori- $D=1.87 \pm 0.29$ ) (Figure 5). The artificial wetland (Bunglung) was the least in diversity $\left(H^{\prime}=1.57 \pm 0.09\right.$ wet, $H^{\prime}=1.36 \pm 0.14$ dry) and species rich $(1.36 \pm 0.18)$ (Figures 3 and 5).

Relationship between Environmental Factors and Bird Assemblage. Canonical correspondence analysis (CCA) diagram showed that bird diversity and abundance were generally influenced by farming practices, bushfires, and grazing intensity although the level of impact varied between the wet and dry seasons (Figures 6 and 7). Although farming practices were a common activity within the catchment of the wetlands in the wet season, the situation was more severe and widespread within $100 \mathrm{~m}$ radius in the artificial wetland, with almost $90 \%$ of the fertile lands cultivated. Birds that were identified in these farmed plots were less diverse, low in abundance, and sensitive to disturbances. Examples included were black-billed dove (Turtur abyssinicus), marsh warbler (Acrocephalus palustris), and the yellow weaver bird (Ploceus megarhrynchus) compared with birds found in the remaining five wetlands. Heavily grazed plots in Wuntori and Tugu shallow marshes, with severe animal trampling, supported high abundance of birds like the African pygmy goose (Nettapus auritus), collared sunbird (Anthreptes collaris), African jacana (Actophilornis africanus), Pied kingfisher (Ceryle rudis), and the squacco heron (Ardeola ralloides) (Figure 6).
Bushfire was the key human-led factor that consistently influenced bird population and diversity in the two riparian wetlands in the dry and wet seasons and a few plots in the Tugu shallow marsh. Observed patchy conditions brought about by previously and recent burnt areas (for the purposes of farm clearing and charcoal production) were more extensive in Adayili and Nabogo forested wetlands than tin Tugu wetland. This disturbance scenario rather attracted diverse birds such as little bee-eater (Merops pusillus), Spotted creeper (Salpornis spilonotus), northern red-billed hornbill (Tockus erythrorhynchus), and Western gray plantain eater (Crinifer piscator) to these wetlands, in spite of the narrow ranges that were created (Figure 6). Majority of species, not captured in the ordination diagrams, were detected in habitats with average conditions of the environmental factors evaluated. Cumulative percentage variance of the speciesenvironment relationship (axis I $=5.54$ and axis II $=10.39$ ) explained $15.93 \%$ of the variation in the weighted averages of the 25 species in relation to three environmental variables in the wet season (Table 3(a)). The rather weak correlation between species-environmental factors in the first three axes $(r=0.430, r=0.523$, and $r=0.320)$ reflected in the high diversity registered in the wet season (Table 3(a)).

The dry season saw water from the three marshes (Kukobila, Wuntori, and Tugu) and Bunglung were drained to irrigate nearby farms. Consequently, birds such as African jacana (Actophilornis africanus), lanner falcon (Falco biarmicus), marsh warbler (Acrocephalus palustris), and black-billed wood dove (Turtur abyssinicus) were confined to the central part of the wetlands that had isolated pools of water and vegetation (Figure 7). Although birds were spatially diverse in these wetlands, they were less abundant. However, the population of yellow billed kite increased in the first $0-10 \mathrm{~m}$ and 10-20 m transect lines, where incidences of bushfire were observed. All the three wetlands with inherent human-led disturbances (grazing intensity and farming activities) were spatially autocorrelated in the dry season (Figure 7).

Cumulative percentage variance was explained by the first two axes (axis $I=8.963$ and axis II $=5.092$ ) and accounted for $14.06 \%$ of the variation in the weighted averages of the 23 species diversity and abundance (Table 3(b)). The low bird diversity recorded in the dry season was further reflected in the strong correlation with the environmental factors on the first three axes of the of the ordination diagram $(r=0.581$, $r=0.644$, and $r=0.629$ ) (Figure 7).

\section{Discussion}

Our study highlighted the growing concern on bird abundance and diversity fluctuations on seasonal scales, as a result of environmental disturbances. The increase in bird density in the wet season, with a corresponding increase in area of lateral distance, was probably due to the abundance of food types, presence of dense vegetation (serving as secured nesting sites against hunting), the near absence of inflammable litter, stable hydrological period, and the importance of plot size ratio to wetland area. Wetlanddependent birds have reportedly used the availability of water as proximate cues to assist in their broad scale selection 
TABLE 1: List of bird species detected and their status, with respect to the IUCN global "Red List" database.

\begin{tabular}{|c|c|c|c|c|}
\hline Family & Scientific name & Bird group & Common name & IUNC status \\
\hline Jacanidae & Actophilornis africana & Coots & African jacana & $\mathrm{LC}$ \\
\hline Anatidae & Nettapus auritus & Bitterns and herons & African pygmy goose & $\mathrm{LC}$ \\
\hline Lybiidae & Lybius dubius & Woodpeckers & Bearded barbet & $\mathrm{LC}$ \\
\hline Columbidae & Turtur abyssinicus & Pigeons and doves & Black-billed dove & $\mathrm{LC}$ \\
\hline Malaconotidae & Tchagra australis & Shricks & Black-crowned tchagra & LC \\
\hline Charadriidae & Vanellus tectus & Plovers and lampings & Black headed plover & $\mathrm{LC}$ \\
\hline Ardeidae & Bubulcus ibis & Bitterns and heron & Cattle egret & $\mathrm{LC}$ \\
\hline Nectariniidae & Anthreptes collaris & Tree creepers & Collared sunbird & $\mathrm{LC}$ \\
\hline Phasianidae & Pternistis bicalcaratus & Pheasants and patridges & Double spurred francolin & $\mathrm{LC}$ \\
\hline Muscicapidae & Muscicapa gambagae & Flycatchers & Gambaga flycatcher & LC \\
\hline Falconidae & Falco biarmicus & Falcons & Lanner falcon & $\mathrm{LC}$ \\
\hline Meropidae & Merops pusillus & Bee eaters & Little bee-eater & $\mathrm{LC}$ \\
\hline Acrocephalidae & Acrocephalus palustris & Warblers & Marsh warbler & LC \\
\hline Ploceidae & Euplectes franciscanus & Finches & Northern red bishop & $\mathrm{LC}$ \\
\hline Bucerotidae & Tockus erythrorhynchus & Hornbills & Northern red hornbill & LC \\
\hline Alcedinidae & Ceryle rudis & Kingfishers & Pied kingfisher & $\mathrm{LC}$ \\
\hline Ploceidae & Quelea quelea & Weavers & Red-billed quelea & $\mathrm{LC}$ \\
\hline Certhiidae & Salpornis spilonotus & Tree creepers & Spotted creeper & $\mathrm{LC}$ \\
\hline Ardeidae & Ardeola ralloides & Waders & Squacco heron & $\mathrm{LC}$ \\
\hline Columbidae & Streptopelia vinacea & Pigeons and doves & Vinaceous dove & $\mathrm{LC}$ \\
\hline Sturnidae & Cinnyricinclus leucogaster & Terns & Violet backed starling & $\mathrm{LC}$ \\
\hline Musophagidae & Crinifer piscator & Touracos & Western gray plantain eater & $\mathrm{LC}$ \\
\hline Ciconiidae & Ciconia episcopus & Waders & Wooly necked stock & $\mathrm{LC}$ \\
\hline Accipitridae & Milvus aegyptius & Swallows & Yellow-billed kite & $\mathrm{LC}$ \\
\hline Ploceidae & Ploceus megarhrynchus & Finches & Yellow weaver bird & VU \\
\hline
\end{tabular}

The status abbreviations are as follows: least concern (LC); vulnerable (VU); threatened (T); near threatened (NT); critical (CR); extinct (EX).

TABLE 2: (a) Mean number of birds counted in a lateral distance per line transect (Wet season). (b) Mean number of birds counted in a lateral distance per line transect (Dry season).

(a)

\begin{tabular}{lcccccc}
\hline Wetland type & $0-10 \mathrm{~m}$ & $10-20 \mathrm{~m}$ & $20-30 \mathrm{~m}$ & $30-40 \mathrm{~m}$ & $40-50$ & $50-60 \mathrm{~m}$ \\
\hline Kukobila & $6.6 \pm 2.5$ & $2 \pm 0.5$ & $4.8 \pm 2.2$ & $6.2 \pm 1.5$ & $6 \pm 1.1$ & $7.4 \pm 2$ \\
Wuntori & $11 \pm 3$ & $9.6 \pm 4.1$ & $8.4 \pm 1.7$ & $7.2 \pm 1.4$ & $3.8 \pm 0.6$ & $6.2 \pm 1.8$ \\
Tugu & $9.8 \pm 4.8$ & $7 \pm 2.8$ & $5.5 \pm 1.9$ & $9.6 \pm 3.6$ & $5.6 \pm 2$ & $4.4 \pm 1.2$ \\
Adayili & $7.6 \pm 3.4$ & $5.4 \pm 1.4$ & $2.8 \pm 0.4$ & $5.8 \pm 2.2$ & $4.4 \pm 1.4$ & $5.2 \pm 1.8$ \\
Nabogo & $9.8 \pm 1.7$ & $7.2 \pm 2.6$ & $9.6 \pm 4.1$ & $7.8 \pm 3.4$ & $6.4 \pm 2.3$ & $11.6 \pm 2.8$ \\
Bunglung & $9 \pm 1.9$ & $4.6 \pm 1.2$ & $7.8 \pm 3.9$ & $5.6 \pm 3.9$ & $4.8 \pm 1.6$ & $3.2 \pm 0.4$ \\
\hline & & $(\mathrm{b})$ & & & \\
& & & $20-30 \mathrm{~m}$ & $30-40 \mathrm{~m}$ & $40-50$ & $50-60 \mathrm{~m}$ \\
\hline Wetland type & $0-10 \mathrm{~m}$ & $10-20 \mathrm{~m}$ & $5.4 \pm 1.4$ & $7.6 \pm 2.4$ & $6.6 \pm 2.2$ & $4.2 \pm 2$ \\
Kukobila & $4.2 \pm 1.8$ & $2.2 \pm 0.5$ & $3.2 \pm 0.9$ & $3.4 \pm 1.3$ & $5 \pm 2.3$ & $3.8 \pm 1.6$ \\
Wuntori & $5.4 \pm 2.2$ & $5.6 \pm 3.4$ & $7.8 \pm 4$ & $7.4 \pm 2.1$ & $9.6 \pm 4.4$ & $3.6 \pm 2.1$ \\
Tugu & $3.6 \pm 0.8$ & $4.6 \pm 1.3$ & $2.4 \pm 1$ & $3.6 \pm 1.9$ & $5.6 \pm 2.5$ & $3.8 \pm 2.1$ \\
Adayili & $4.8 \pm 1.9$ & $5.2 \pm 1.2$ & $6.6 \pm 1.4$ & $4.2 \pm 0.7$ & $4 \pm 1.2$ & $3 \pm 0.9$ \\
Nabogo & $8.8 \pm 1.6$ & $2 \pm 0.8$ & $7.4 \pm 4.5$ & $5.8 \pm 1.9$ & $6.2 \pm 2.2$ & $3.6 \pm 0.7$ \\
Bunglung & $6.2 \pm 2.7$ & $7 \pm 2.4$ & & & & \\
\hline
\end{tabular}


TABLE 3: (a) Summary of CCA axis lengths for birds, showing the levels of correlation between axes and environmental gradients, percentage variance of species, and species-environment relationships (wet season). (b) Summary of CCA axis lengths for birds, showing the levels of correlation between axes and environmental gradients, percentage variance of species, and species-environment relationships (dry season).

(a)

\begin{tabular}{lccc}
\hline & Axis 1 & Axis 2 & Axis 3 \\
\hline Canonical eigenvalues for bird species & 0.163 & 0.143 & 0.078 \\
Pearson correlation species-environmental scores & 0.722 & 0.795 & 0.558 \\
Kendall rank correlation sp-env'tal scores & 0.430 & 0.523 & 0.320 \\
Cumulative percentage variance & 5.54 & 10.39 & 13.05 \\
\% variance explained & 5.54 & 4.85 & 2.66
\end{tabular}

Number of sites $=30$

Number of species (response variables) $=25$

Number of environmental variables $=3$

(b)

\begin{tabular}{lccc}
\hline & Axis 1 & Axis 2 & Axis 3 \\
\hline Canonical eigenvalues for bird species & 0.29 & 0.16 & 0.10 \\
Pearson correlation sp-environmental scores & 0.86 & 0.65 & 0.61 \\
Kendall rank correlation for sp-env'tal scores & 0.58 & 0.64 & 0.63 \\
Cumulative percentage variance & 8.97 & 14.1 & 17.2 \\
\% variance explained & 8.96 & 5.09 & 3.14
\end{tabular}

Number of sites $=30$

Number of species (response variables) $=25$

Number of environmental variables $=3$

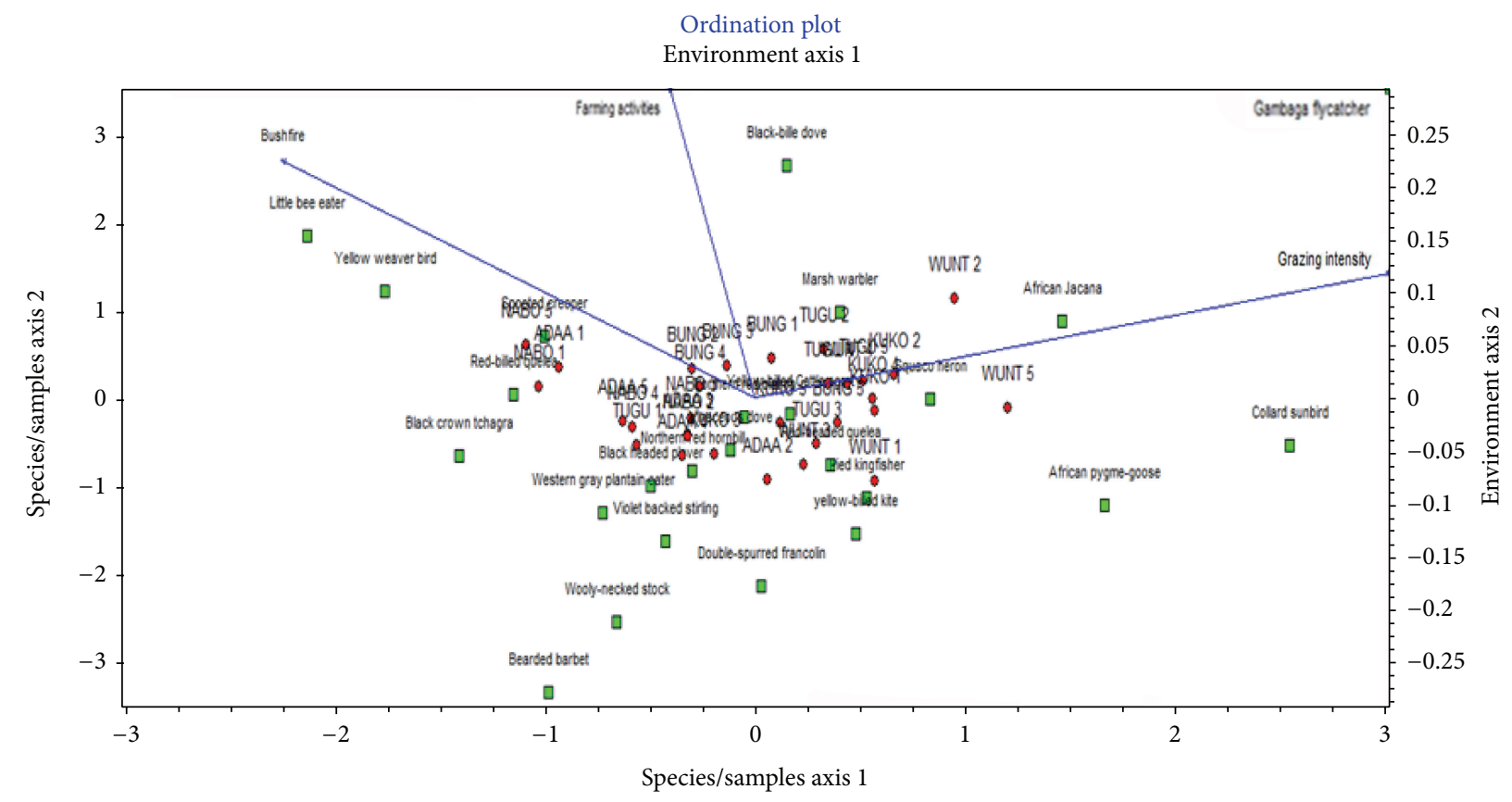

FIGURE 6: Canonical correspondence analysis (CCA) ordination diagram, showing the relationship between environmental variables and bird species across the six wetlands, in the wet season. The red circles represent sample plots, the green squares represent bird species, and the arrows represent each of the environmental variables plotted pointing in the direction of maximum change of explanatory variables across the six wetlands. 


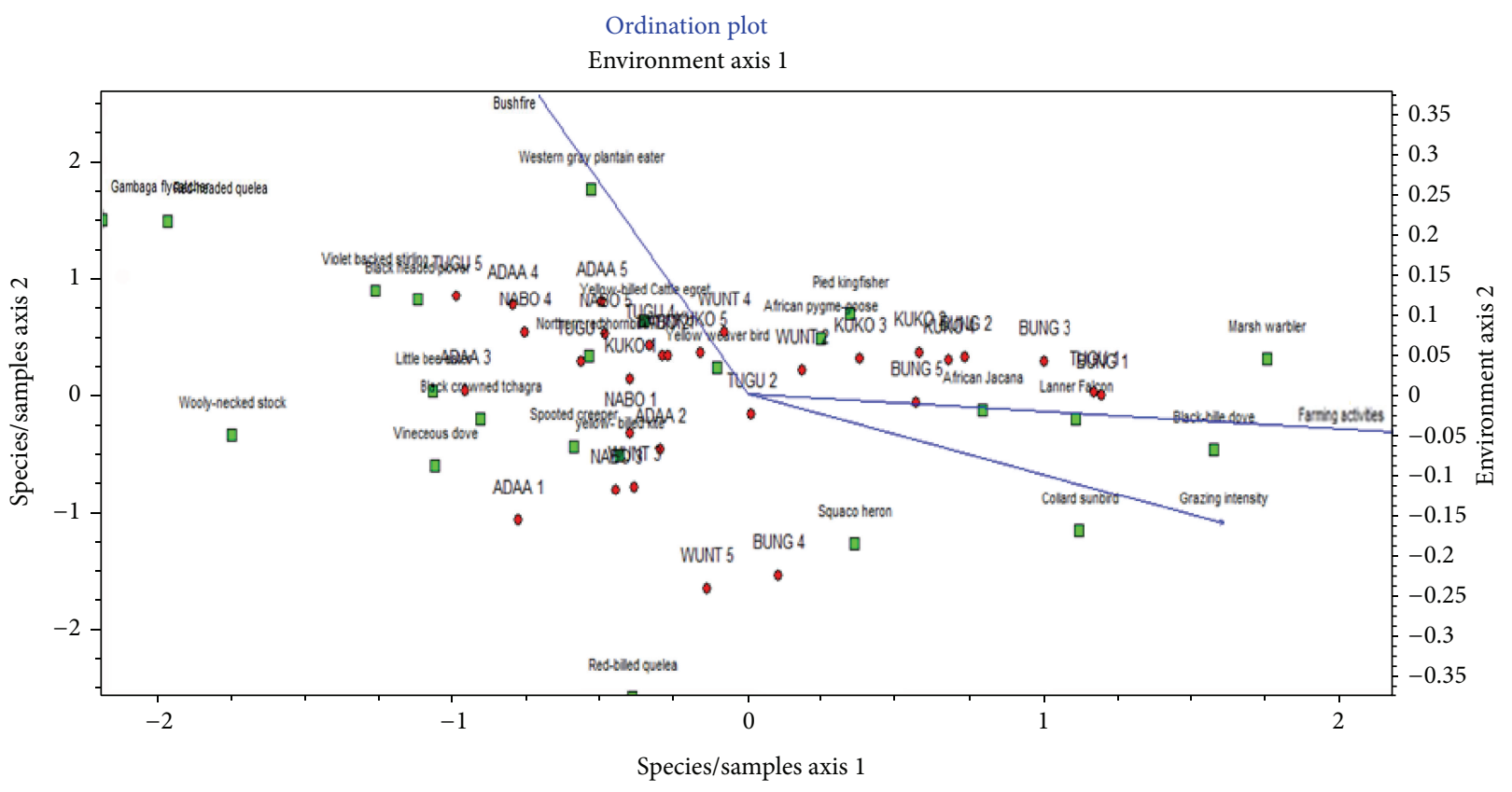

FIGURE 7: Canonical correspondence analysis (CCA) ordination diagram showing the relationship between environmental factors and bird assemblage in the six wetlands in the dry season. Diagram description is the same as in Figure 6.

of habitat preference $[42,43]$, while wetland size has been observed to correlate with higher densities of bird species in North Dakota semipermanent wetlands [5]. For the dry season, we observed that marsh-dependent birds (African jacana, marsh warbler, and squacco heron), whose population are largely dependent on stable hydrological regime [44, 45], were confined to isolated pools of water, as a result of water abstraction for irrigation activities. However, the abundance of riparian preferred species (Spooted creeper, little beeeater, and northern red-billed hornbill) may be due to the attraction (using their proximate cues) to leftover carcasses, following burning and long-term adaption to bushfire landscape conditions. Field experiment conducted by [46] found five out of 35 birds in unburned sites in a Florida wetland, while [47] also detected an increase in the abundance of upland sandpipers (Bartramia longicauda) following burning and grazing activities. But other studies have rather shown a decline in the population of some birds like honeyeaters, through postmortality of bushfires, predation, and food scarcity in Australian wetlands [48]. These varied responses to bushfires are more of species-specific at different spatiotemporal to long-term scales.

With reference to the IUCN "Red List" database (2011) we noted that bird status following the influence of environmental disturbances appears not to be under severe threat, since $96.2 \%$ were categorized as least concern (LC) and 3.8\% (yellow weaver bird (Ploceus megarhrynchus)) as vulnerable (VU). These species were among the least counted and lived on narrow range habitat, predominated by vegetation type (Diplachne fusca, a rough serrated grass species, and Ziziphus abyssinica, a thorny tree) that protect them against hunting for their aesthetic value. But there is the likelihood that current trends of disturbances could in the near future see many birds under least concern status becoming vulnerable if not completely extinct. This is evidenced from the relatively low number of species (26 species) encountered in this study, compared to 48 species of water birds detected in four coastal wetlands of Ghana [22]. The low diversity indices in this study $\left(H^{\prime}=1.24-1.75\right)$ compared to the indices provided by [39] (ranging from 1.5 to 3.5 and occasionally surpasses 4.5) and those reported by [49] $\left(H^{\prime}=3.99\right)$ in the Taunsa Barrage Wildlife Sanctuary-Pakistan reflect the threats to predicted future vulnerabilities of birds in the study sites. The reported decline in the global diversity of habitat-specific birds and shorebird populations, since 19802007 [50], has been predicted to continue at a rate not less than $80 \%$ [51]. The current study identified farming activities, grazing pressure, and bushfires as the factors that affected bird diversity. Other findings identified pollution [4], cutting of mangrove vegetation [8], and hydrological regime $[44,45]$.

\section{Conclusion}

Generally, bird diversity and abundance were largely influenced farming activities and bushfire, and the impacts varied according to the season and the type of wetland. Although farming activities and bushfire encouraged the presence of some bird species, the overall impacts of these environmental determinants negated the role of the disturbance scenario and hence may not be entirely recommended as conservation measure to increase bird population and diversity. Furthermore, considering the fact that the yellow weaver bird was identified as a vulnerable species (VU) gives an indication that the current environmental disturbances observed during 
the study could in the near future affect the population of the remaining $96.2 \%$ of birds classified presently as least concern (LC).

\section{Conflict of Interests}

The authors declare that there is no conflict of interests regarding the publication of this paper.

\section{Acknowledgment}

The authors express their sincere gratitude to the Ghana Education Trust Fund (GETfund), for supporting this research work.

\section{References}

[1] T. J. Davis, Ed., The Ramsar Convention Manual: A Guide to the Convention on Wetlands of International Importance Especially as Waterfowl Habitat, Ramsar Convention Bureau, Gland, Switzerland, 6th edition, 1994.

[2] Birdlife International, Threatened Birds of the World, Lynx Editions/Birdlife International, Barcelona, Spain, 2011.

[3] C. W. Schwartz and E. R. Schwartz, "An ecological reconnaissance of the pheasants of Hawaii," The Auk, vol. 68, no. 3, pp. 281-314, 1951.

[4] C. Gordon, K. Yankson, C. V. Biney, J. W. Tumbolto, D. S. Amlalo, and D. Kpelle, Report of the Working Group on Wetland Typology. Report to Ghana Coastal Wetlands Management Project, Ghana Wildlife Department, Accra, Ghana, 1998.

[5] H. A. Kantrud and R. E. Stewart, "Ecological distribution and crude density of breeding birds on prairie wetlands," Journal of Wildlife Management, vol. 48, no. 2, pp. 426-437, 1984.

[6] D. J. Twedt and C. R. Loesch, "Forest area and distribution in the Mississippi alluvial valley: implications for breeding bird conservation," Journal of Biogeography, vol. 26, no. 6, pp. 12151224, 1999.

[7] R. Sallabanks, J. R. Walters, and J. A. Collazo, "Breeding bird abundance in bottomland hardwood forests: habitat, edge, and patch size effects," The Condor, vol. 102, no. 4, pp. 748-758, 2000.

[8] D. K. Attuqueyefio and F. Gbogbo, "Prospects of conserving wetlands along the Mukwe Lagoon at Nungua in the Greater Accra Region of Ghana," West African Journal of Applied Ecology, vol. 2, pp. 65-75, 2001.

[9] W. J. Mitsch and J. G. Gooselink, Wetlands, John Wiley \& Sons, New York, NY, USA, 3rd edition, 2000.

[10] J. Biggs, P. Williams, M. Whitfield, P. Nicolet, and A. Weatherby, "15 years of pond assessment in Britain: results and lessons learned from the work of pond conservation," Aquatic Conservation: Marine and Freshwater Ecosystems, vol. 15, no. 6, pp. 693-714, 2005.

[11] A. D. Fox, J. Madsen, H. Boyd et al., "Effects of agricultural change on abundance, fitness components and distribution of two arctic-nesting goose populations," Global Change Biology, vol. 11, no. 6, pp. 881-893, 2005.

[12] L. D. Kangah-Kesse, D. K. Attuquayefio, E. H. Owusu, and F. Gbogbo, "Bird species diversity and abundance in the abiriw sacred grove in the Eastern region of Ghana," West African Journal of Applied Ecology, vol. 11, pp. 41-50, 2007.

[13] G. Niemi, J. Hanowski, P. Helle et al., "Ecological sustainability of birds in boreal forests," Conservation Ecology, vol. 2, no. 2, article 17, 1998.
[14] J. D. Brawn, S. K. Robinson, and F. R. Thompson III, “The role of disturbance in the ecology and conservation of birds," Journal of Annual Review of Ecological Systems, vol. 32, pp. 251-276, 2001.

[15] E. H. Owusu, "The ornithological importance of the Amansuri Community Nature Reserve in the Western Region of Ghana," Journal of Science and Technology, vol. 27, no. 3, pp. 72-85, 2007.

[16] E. H. Owusu, "The perceptions of local communities towards the conservation of birds in an important bird area in Ghana," West African Journal of Applied Ecology, vol. 13, no. 1, pp. 111-116, 2008.

[17] R. Demey and A. Hester, "First records of Nimba Flycatcher Melaenornis annamarulae for Ghana," Bulletin of the African Bird Club, vol. 15, no. 1, pp. 95-96, 2008.

[18] Y. Ntiamoa-Baidu, S. K. Nyame, and A. A. Nuoh, "Trends in the use of a small coastal lagoon by waterbirds: Muni Lagoon (Ghana)," Biodiversity \& Conservation, vol. 9, no. 4, pp. 527-539, 2000.

[19] Y. Ntiamoa-Baidu, E. H. Owusu, S. Asamoah, and K. OwusuBoateng, "Distribution and abundance of forest birds in Ghana," Ostrich, vol. 71, no. 1-2, pp. 262-267, 2000.

[20] Y. Ntiamoa-Baidu, S. A. Asamoah, E. H. Owusu, and K. OwusuBoateng, "Avifauna of two upland evergreen forest reserves, the Atewa range and Tano Offin, in Ghana," Ostrich, vol. 71, no. 1-2, pp. 277-280, 2000.

[21] R. H. Suapim, D. K. Attuquayefio, F. Gbogbo, and E. H. Owusu, "Aspects of the feeding ecology of wintering water birds in the Densu Delta Ramsar Site, Ghana," Ghana Journal of Science, vol. 47, pp. 17-34, 2007.

[22] F. Gbogbo and D. K. Attuquayefio, "Issues arising from changes in water bird population estimates in coastal Ghana," Journal of Bird Populations, vol. 10, pp. 79-87, 2000.

[23] E. A. Obodai and C. A. Nsor, "Aspects of biodiversity and fish production in the Kukobila wetland in the Savelugu-Nanton District of the Northern Region of Ghana," Ethiopian Journal of Environmental Studies and Management, vol. 2, no. 3, pp. 27-35, 2009.

[24] Birdlife International, Threatened Birds of the World, Lynx Editions/Birdlife International, Barcelona, Spain, 2000.

[25] Ministry of Environment and Science, National Biodiversity Strategy for Ghana Report, Ministry of Environment and Science, Ghana, 2002.

[26] T. Slaymaker and R. M. Blench, Rethinking Natural Resource Degradation in Sub-Saharan Africa: Policies to Support Sustainable Soil Fertility Management, Soil and Water Conservation among Resource Poor Farmers in Semi-Arid Areas: Country Studies. I, University of Development Studies, Tamale, Ghana, 2002.

[27] W. J. Sutherland, Ecological Census Techniques, Cambridge University Press, Cambridge, UK, 2nd edition, 2006.

[28] S. T. Buckland, D. R. Anderson, K. P. Burnham, and J. L. Laake, Distance Sampling: Estimating Abundance of Biological Populations, Chapman \& Hall, New York, NY, USA, 2003.

[29] C. J. Bibby, N. D. Burgess, D. A. Hill, and S. H. Mustoe, Bird Census Techniques, Academic Press, New York, NY, USA, 2nd edition, 2000.

[30] Birds of Ghana Galleries, 2010, http://www.pbase.com/.

[31] R. J. Hobbs and L. F. Huenneke, "Disturbance, diversity, and invasion: implications for conservation," Conservation Biology, vol. 6, no. 3, pp. 324-337, 1992.

[32] W. J. Sutherland, The Conservation Handbook, CAPConservation Action Planning, Blackwell Science, Massachusetts TNC-WWF (The Nature Conservancy World Wide Fund 
for Nature), Massachusetts, Mass,USA, 2000, http://conserveonline.org/workspaces/cbdgateway/resources.

[33] N. Salafsky, R. Margoluis, K. H. Redford, and J. G. Robinson, "Improving the practice of conservation: a conceptual framework and research agenda for conservation science," Conservation Biology, vol. 16, no. 6, pp. 1469-1479, 2002.

[34] N. Salafsky, D. Salzer, and J. Ervin, Conventions for defining, naming, measuring, combining, and mapping threats in conservation. An initial proposal for a standard system, 2003, http://www.fosonline.org/resource/conventions-for-threats.

[35] N. Salafsky, D. Salzer, A. J. Stattersfield et al., "A standard lexicon for biodiversity conservation: unified classifications of threats and actions," Conservation Biology, vol. 22, no. 4, pp. 897-911, 2008.

[36] C. Battisti, L. Luiselli, and C. Teofili, "Quantifying threats in a Mediterranean wetland: are there any changes in their evaluation during a training course?" Biodiversity and Conservation, vol. 18, no. 11, pp. 3053-3060, 2009.

[37] C. J. F. Ter Braak, "Canonical correspondence analysis: a new eigenvector technique for multivariate direct gradient analysis," Ecology, vol. 67, no. 5, pp. 1167-1179, 1986.

[38] P. A. Henderson and R. M. Seaby, Environmental Community Analysis 1.3, Pisces Conservation Ltd, Hampshire, UK, 2000.

[39] C. E. Shannon and W. Weaver, The Mathematical Theory of Communication, The University of Illinois Press, Urbana, Ill, USA, 1963.

[40] E. C. Pielou, An introduction to Mathematical Ecology, John Wiley \& Sons, New York, NY, USA, 1969.

[41] R. Margalef, Perspective in Ecological Theory, University of Chicago Press, Chicago, Ill, USA, 1968.

[42] J. A. Kushland, "Responses of wading birds to seasonally fluctuating water levels strategies and their limits," Journal of Colonial Water, vol. 9, pp. 155-162, 1987.

[43] J.E. Austin, "Responses of dabbling ducks to wetland conditions in the Prairie Pothole region," Journal of Waterbirds, vol. 25, no. 4, pp. 465-473, 2002.

[44] F. Causarano, C. Battisti, and A. Sorace, "Effect of winter water stress on the breeding bird assemblage of a remnant wetland in Central Italy,' Revue d'Ecologie, vol. 64, no. 1, pp. 61-72, 2009.

[45] D. Zacchei, C. Battisti, and G. M. Carpaneto, "Contrasting effects of water stress on wetland-obligated birds in a seminatural Mediterranean wetland," Lakes and Reservoirs: Research and Management, vol. 16, no. 4, pp. 281-286, 2011.

[46] R. J. Vogl, "Effects of fire on the plants and animals of a Florida wetland," American Midland Naturalist, vol. 89, no. 2, pp. 334347, 1973.

[47] A. F. L. A. Powell, "Effects of prescribed burns and bison (Bos bison) grazing on breeding bird abundances in tallgrass prairie," Auk, vol. 123, no. 1, pp. 183-197, 2006.

[48] M. Allen, "Wetlands and Fire. Water and Rivers Commission. Water Notes for Wetlands Managers. WNS2," Natural Heritage Trust, Australia, 2000.

[49] F. Bibi and Z. Ali, "Measurement of diversity indices of avian communities at Taunsa Barrage Wildlife Sanctuary, Pakistan," Journal of Animal and Plant Sciences, vol. 23, no. 2, pp. 469-474, 2013.

[50] S. H. Butchart, M. Walpole, B. Collen et al., "Global biodiversity: indicators of recent declines," Science, vol. 328, no. 5982, pp. 1164-1168, 2010.

[51] F. Von Euler, "Selective extinction and rapid loss of evolutionary history in the bird fauna," Proceedings of the Royal Society B: Biological Sciences, vol. 268, no. 1463, pp. 127-130, 2001. 

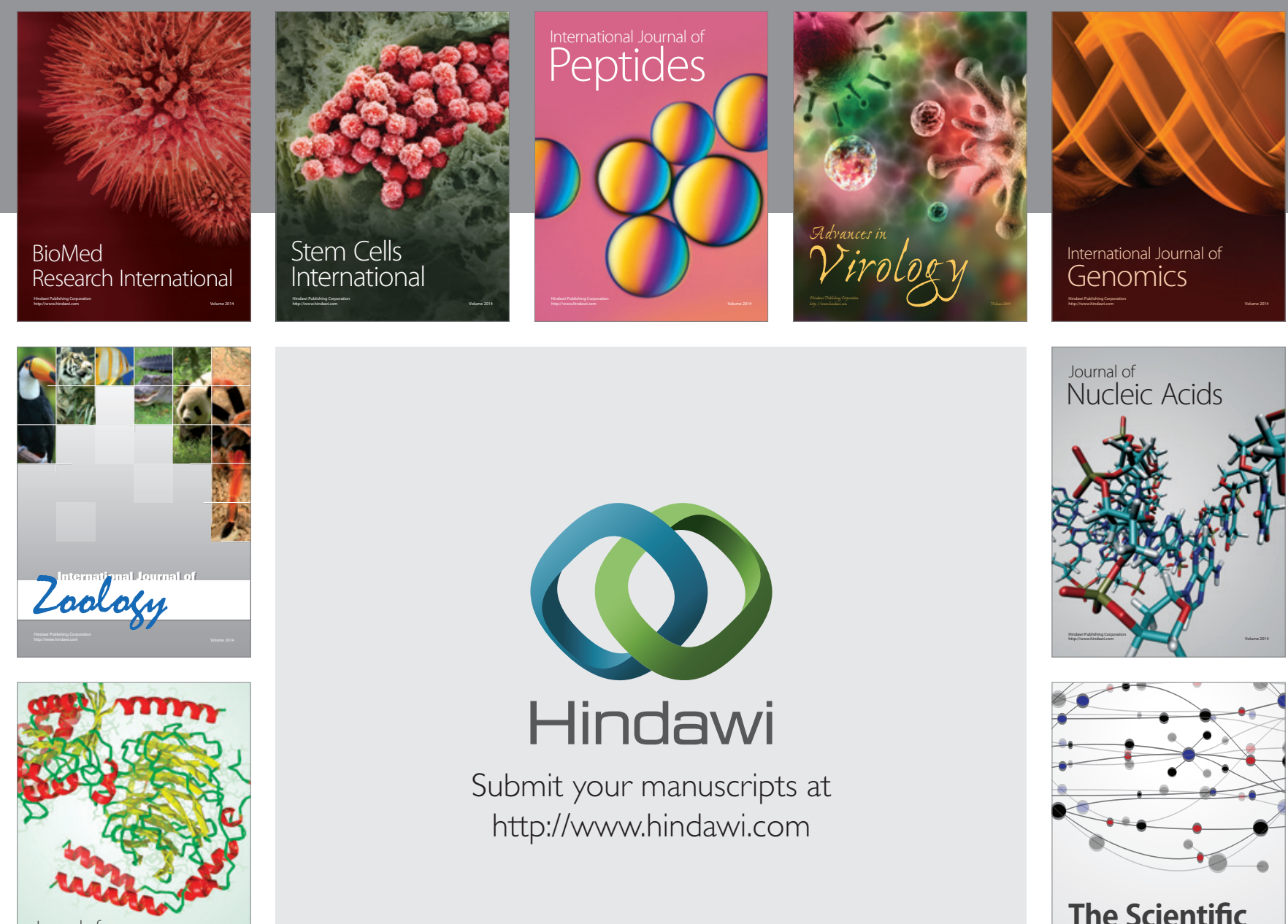

Submit your manuscripts at

http://www.hindawi.com

Journal of
Signal Transduction
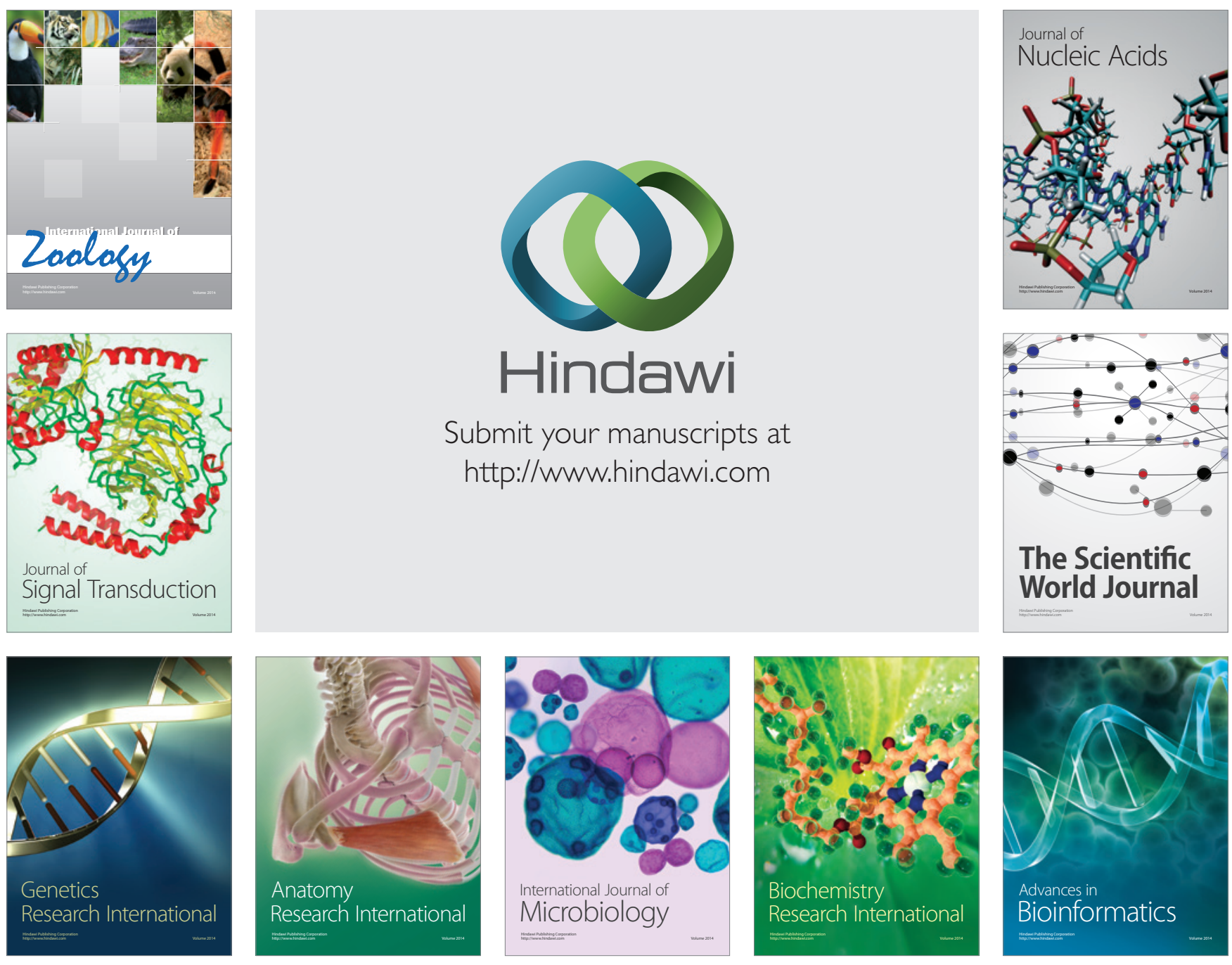

The Scientific World Journal
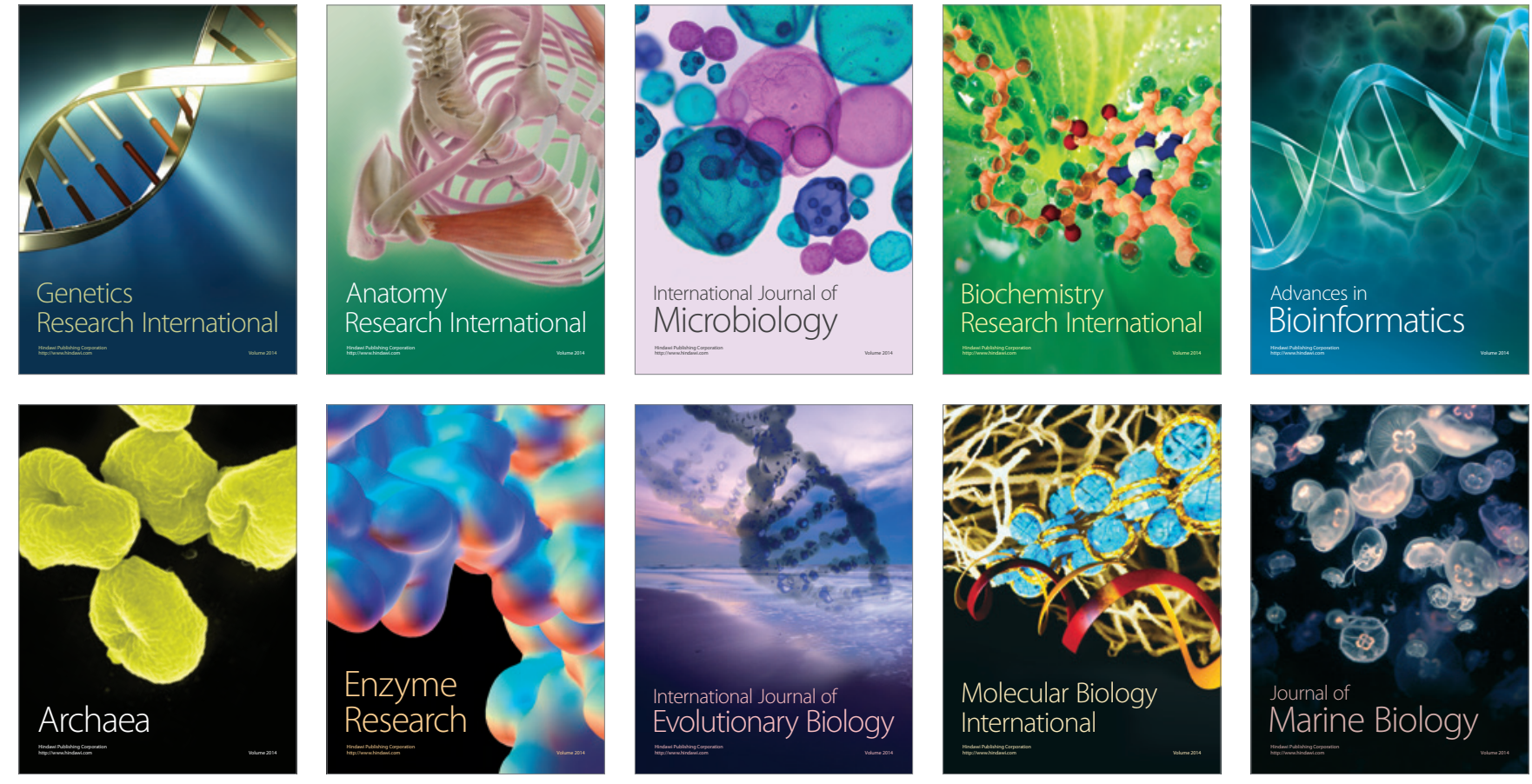